Check for updates

Cite this: RSC Adv., 2018, 8, 24203

Received 6th May 2018

Accepted 14th June 2018

DOI: $10.1039 / \mathrm{c} 8 \mathrm{ra03870h}$

rsc.li/rsc-advances

\title{
Cu-MOF: an efficient heterogeneous catalyst for the synthesis of symmetric anhydrides via the $\mathrm{C}-\mathrm{H}$ bond activation of aldehydes $\uparrow$
}

\author{
Zahra Ahmadzadeh, Javad Mokhtari (iD * and Morteza Rouhani \\ In this paper, an efficient and straightforward synthetic approach for the preparation of a number of \\ symmetric carboxylic anhydrides was reported using $\mathrm{Cu}_{2}(\mathrm{BDC})_{2}(\mathrm{DABCO})$ as an efficient heterogeneous \\ catalyst via the $\mathrm{C}-\mathrm{H}$ bond activation of aldehydes with excellent yields and simple work up. This $\mathrm{C}-\mathrm{H}$ \\ bond activation reaction appears simple and convenient, has a wide substrate scope and makes use of \\ cheap, abundant, and easily available reagents. The Cu-MOF catalyst was recycled and reused four times \\ without any loss of catalytic activity.
}

\section{Introduction}

Metal-organic frameworks (MOFs), which are also called coordination polymers, ${ }^{1}$ are synthesized from organic linkers and metal ions or clusters. ${ }^{2}$ Recently, MOFs have attracted much more attention due to their structural and chemical diversities and have become very popular in diverse research areas such as catalysis ${ }^{3-5}$ drug delivery, ${ }^{6,7}$ gas storage, ${ }^{8,9}$ adsorption, ${ }^{10,11}$ chemical sensing, ${ }^{12}$ conversion ${ }^{13}$ etc.

In spite of their low thermal and chemical stabilities which have limited their applications to only those under mild conditions, MOFs have achieved more attention in chemical catalysis. ${ }^{14}$ Their efficient catalytic activities are caused by several parameters such as the existence of suitable functional groups on the organic linkages, the flexibility of the framework which facilities the acceptance of the guest molecule(s), the internal channel surface area etc. ${ }^{15-17}$ The active metal sites in MOFs are fully exposed and thus provide a high degree of metal dispersion. In addition, MOFs provide a highly versatile alternative to well-established porous materials by constructing various transition metal nodes and a wide variety of organic bridging ligands for specific catalytic applications. ${ }^{18}$ Among MOFs, Cu-MOFs have attracted more interest because of their outstanding catalytic activities, regular structural configuration and some dominant electrical properties. ${ }^{18}$

Anhydrides belong to the carboxylic acid derivatives and are very useful reagents in organic synthesis ${ }^{19}$ and various other reactions including the lactonization of silyl esters, ${ }^{20}$ asymmetric esterifications, ${ }^{21}$ the condensation reaction of free carboxylic acids and alcohols $\mathrm{s}^{22}$ and specially in the preparation of peptides

Department of Chemistry, Science and Research Branch, Islamic Azad University, P.O. Box 14515/775, Tehran, Iran.E-mail: j.mokhtari@srbiau.ac.ir

$\dagger$ Electronic supplementary information (ESI) available. See DOI: $10.1039 / \mathrm{c} 8 \mathrm{ra} 03870 \mathrm{~h}$ and drugs. ${ }^{23}$ Symmetric anhydrides are well known as advantageous acylating agents because they prevent by-product generation due to their symmetric nature. ${ }^{24}$ The main classical synthetic procedures for anhydride synthesis involve utilizing dehydrating agents such as phosgene, acid chloride, thionyl chloride, benzenesulfonyl chloride, and phosphorous pentoxide in equivalent amounts which generally need harsh reaction conditions, are usually expensive, have inaccessible reagents and catalysts, have a time-consuming work-up etc. (Scheme 1). ${ }^{25,26}$

For these reasons, researchers are always looking for novel synthetic pathways which provide straightforward access to the desired anhydrides within a minimum reaction time with inexpensive starting materials and catalysts as well as mild reaction conditions..$^{27-29}$ A new approach involves the self-coupling of aldehydes in the presence of transition metal catalysts such as
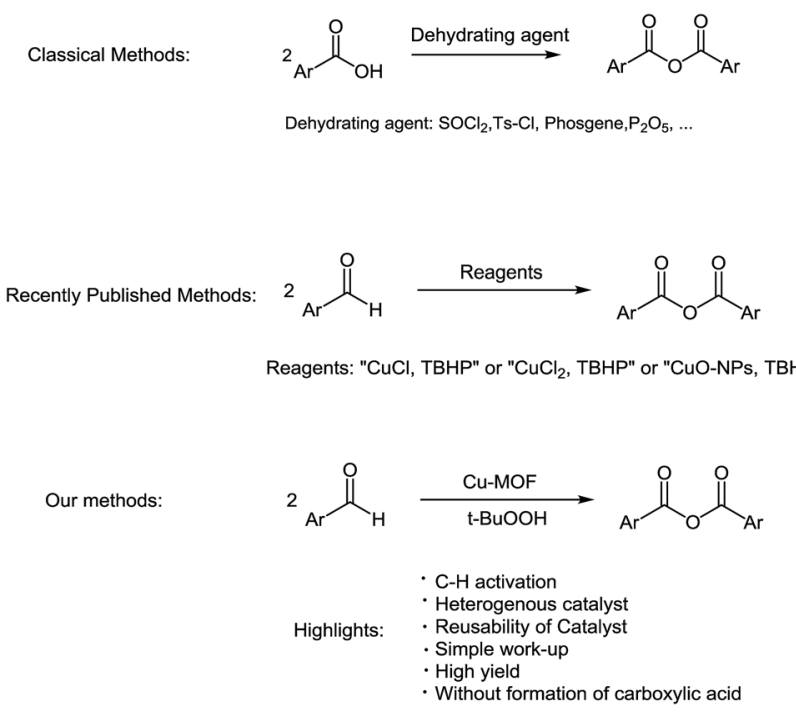

Scheme 1 Different methods for the synthesis of anhydrides. 
<smiles>[R][R]1ccc(C=O)cc1</smiles>
1

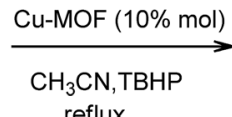

reflux

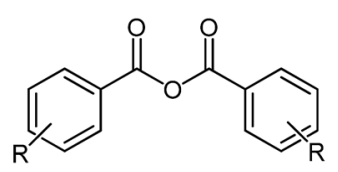

Scheme 2 The $\mathrm{Cu}_{2}(\mathrm{BDC})_{2}(\mathrm{DABCO})$ catalyzed synthesis of anhydrides via $\mathrm{C}-\mathrm{H}$ aldehyde bond activation.

copper. ${ }^{30-32}$ A major drawback related to earlier methodologies is homogeneous systems and as a result, the isolation of catalysts and work-up are difficult and time consuming. Therefore, the development of new heterogeneous systems for the formation of $\mathrm{C}-\mathrm{O}$ bonds through $\mathrm{C}-\mathrm{H}$ bond activation remains a great goal. A few examples were reported for $\mathrm{C}-\mathrm{O}$ bond formation via $\mathrm{C}-\mathrm{H}$ aldehyde bond activation. ${ }^{33}$ Corma $^{34}$ recently published an example for $\mathrm{C}-\mathrm{O}$ bond formation via $\mathrm{C}-\mathrm{H}$ aldehyde bond activation with $\mathrm{Cu}-\mathrm{MOF}$ as the heterogeneous catalyst.

So, according to what is mentioned above and in continuation of our interest in exploring the role of MOFs as efficient heterogeneous catalysts in organic synthesis and oxidative coupling reactions, ${ }^{35-37}$ herein, we report the first application of Cu-MOFs as efficient heterogeneous catalysts for the synthesis of symmetric carboxylic anhydrides 2 via the $\mathrm{C}-\mathrm{H}$ activation of aldehydes $\mathbf{1}$ using TBHP as an oxidizing agent (Scheme 2). Good to excellent yields, easy work-up of the catalyst, reusability, and minimal reaction time are some of the beneficial features of this reaction.

\section{Experimental section}

\section{Materials and methods}

All of the chemicals were purchased from commercial sources and used without further purification. $\mathrm{Cu}_{2}(\mathrm{BDC})_{2}(\mathrm{DABCO})$ was synthesized according to a previously reported procedure. ${ }^{37}$ All of the reactions were monitored by thin layer chromatography (TLC) using plates coated with Merck $60 \mathrm{HF} 254$ silica under UV light. The BET (Brunauer-Emmett-Teller) surface area of the samples was determined from $\mathrm{N}_{2}$ adsorption-desorption isotherms using a micromeritics ASAP 2020 analyzer. The sample was characterized using a ZEISS scanning electron microscope (SEM) at $30 \mathrm{kV}$ with a gold coating. Transmission electron microscopy (TEM) was carried out using an EM10C-100 $\mathrm{kV}$ series microscope from the Zeiss Company, Germany. A TGA/DSC (thermogravimetric analysis \& differential scanning calorimetry) by METTLER TOLEDO, Switzerland, was used for thermogravimetric analysis (TGA) with a heating rate of $10{ }^{\circ} \mathrm{C} \min ^{-1}$ under a nitrogen atmosphere. FT-IR spectra were recorded using a Shimadzu 8400s FT-IR spectrometer. ${ }^{1} \mathrm{H}-\mathrm{NMR}$ spectra were recorded with a BRUKER DRX 500-AVANCE FTNMR instrument $\left(\mathrm{CDCl}_{3}\right.$ solution $)$ at $500 \mathrm{MHz}$.

Synthesis of carboxylic anhydrides via the $\mathrm{C}-\mathrm{H}$ activation of aldehydes catalyzed by $\mathrm{Cu}_{2}(\mathrm{BDC})_{2}$ (DABCO)

To a solution of aldehyde $1(1 \mathrm{mmol})$ and $\mathrm{Cu}_{2}(\mathrm{BDC})_{2}(\mathrm{DABCO})$ $(10 \% \mathrm{~mol})$ in $\mathrm{CH}_{3} \mathrm{CN}(2 \mathrm{ml}), 1.5$ eq. from a $6 \mathrm{M}$ solution of TBHP in $\mathrm{CH}_{3} \mathrm{CN}$ was added slowly over 5 minutes while stirring. Then, the reaction temperature was increased to $80{ }^{\circ} \mathrm{C}$ and was allowed to be stirred for $2 \mathrm{~h}$. The reaction progress was monitored by TLC. After completion of the reaction, the solvent was evaporated under reduced pressure, and the residue was purified using silica gel column chromatography (hexane/ethyl acetate $(10: 4))$.

\section{Selected spectra data}

Benzoic anhydride (2a). Yield $=82 \%$; liquid, ${ }^{1} \mathrm{H}-\mathrm{NMR}(500$ $\left.\mathrm{MHz}, \mathrm{CDCl}_{3}\right): \delta 7.46-7.51(\mathrm{~m}, 4 \mathrm{H}, \mathrm{CH}$ of $\mathrm{Ar}), 7.60-7.65(\mathrm{~m}, 2 \mathrm{H}$, $\mathrm{CH}$ of $\mathrm{Ar}), 8.13\left(\mathrm{~d}, 4 \mathrm{H},{ }^{3} \mathrm{~J}=7.86 \mathrm{~Hz}\right)$. Anal. calcd for $\mathrm{C}_{14} \mathrm{H}_{10} \mathrm{O}_{3}$ (226.23): C, 74.33; H, 4.46. Found: C, 74.35; H, 4.47.

4-Nitrobenzoic anhydride (2i). Yield $=68 \%$; mp: $188-190{ }^{\circ} \mathrm{C}$, ${ }^{1} \mathrm{H}-\mathrm{NMR}\left(500 \mathrm{MHz}, \mathrm{CDCl}_{3}\right): \delta 8.14\left(\mathrm{~d}, 4 \mathrm{H},{ }^{3} \mathrm{~J}=8.9 \mathrm{~Hz}, \mathrm{CH}\right.$ of $\mathrm{Ar}$ ), $8.26\left(\mathrm{~d}, 4 \mathrm{H},{ }^{3} \mathrm{~J}=8.9 \mathrm{~Hz}, \mathrm{CH}\right.$ of $\mathrm{Ar}$ ). Anal. calcd for $\mathrm{C}_{14} \mathrm{H}_{8} \mathrm{~N}_{2} \mathrm{O}_{7}$ (316.23): C, 53.18; H, 2.55; N, 8.86\%. Found: C, 53.21; H, 2.58; N, $8.87 \%$.

4-Hydroxy-3-methoxybenzoic anhydride (2m). Yield $=73 \%$; ${ }^{1} \mathrm{H}-\mathrm{NMR}\left(500 \mathrm{MHz}, \mathrm{CDCl}_{3}\right.$ ): $\delta 3.98$ (s, 6H, MeO), 6.17 (bs, 2H, $\mathrm{OH}$ ), 7.05 (d, $2 \mathrm{H},{ }^{3} \mathrm{~J}=8.4 \mathrm{~Hz}, \mathrm{CH}$ of $\mathrm{Ar}$ ), 7.43-7.45 (m, $4 \mathrm{H}, \mathrm{CH}$ of Ar). Anal. calcd for $\mathrm{C}_{16} \mathrm{H}_{14} \mathrm{O}_{7}$ (318.28): C, 60.38; H, 4.43. Found: C, 60.4; H, 4.46.

4-Hydroxybenzoic anhydride (2l). Yield $=70 \% ;{ }^{1} \mathrm{H}-\mathrm{NMR}(500$ $\mathrm{MHz} \mathrm{CDCl}_{3}$ ): $\delta 5.6$ (bs, 2H, OH), $6.95\left(\mathrm{~d}, 4 \mathrm{H},{ }^{3} \mathrm{~J}=8.6 \mathrm{~Hz}, \mathrm{CH}\right.$ of $\mathrm{Ar}), 7.82\left(\mathrm{~d}, 4 \mathrm{H},{ }^{3} J=8.6 \mathrm{~Hz}, \mathrm{CH}\right.$ of $\left.\mathrm{Ar}\right)$. Anal. calcd for $\mathrm{C}_{14} \mathrm{H}_{10} \mathrm{O}_{5}$ (258.23): C, 65.12; H, 3.90. Found: C, 65.15; H, 3.94.

\section{Results and discussion}

In this work, $\mathrm{Cu}_{2}(\mathrm{BDC})_{2}(\mathrm{DABCO})$ was synthesized and characterized by various techniques and according to our previously reported procedure. The XRD powder patterns of the resulting solid were compared to the previously reported ones and sharp peaks were present at $8 \theta$ and $9 \theta$, which confirmed the formation of $\mathrm{Cu}_{2}(\mathrm{BDC})_{2}(\mathrm{DABCO})^{37}$ (Fig. 2). The FT-IR spectra of $\mathrm{Cu}_{2}(-$ $\mathrm{BDC})_{2}(\mathrm{DABCO})$ exhibited the formation of $\mathrm{Cu}_{2}(\mathrm{BDC})_{2}(\mathrm{DABCO})$ compared to our previous reports ${ }^{37}$ (Fig. S5a $\dagger$ ). The nitrogen adsorption isotherm of $\mathrm{Cu}_{2}(\mathrm{BDC})_{2}(\mathrm{DABCO})$ presented a typical type-I profile with a relatively high Langmuir surface area of $1496 \mathrm{~m}^{2} \mathrm{~g}^{-1}$ (Fig. S1 $\dagger$ ) and a median pore diameter of $3.9 \mathrm{~nm}$ (Fig. S1 $\dagger$ ). TGA results indicated that the material was stable up to over $250{ }^{\circ} \mathrm{C}$ (Fig. S6 $\dagger$ ). A SEM micrograph (Fig. S3 $\dagger$ ), consistent with the TEM observation (Fig. S4 $\dagger$ ), confirmed that a highly crystalline material was achieved.

The synthetic $\mathrm{Cu}_{2}(\mathrm{BDC})_{2} \mathrm{DABCO}$ was employed as a catalyst in the $\mathrm{C}-\mathrm{H}$ activation of aldehydes and the synthesis of anhydrides. Firstly, to achieve the optimum reaction conditions, various parameters such as the solvent, the oxidant, the amount of catalyst and the reaction time were examined.

\section{Selection of the best solvent}

The effect of various solvents such as dichloromethane $\left(\mathrm{CH}_{2} \mathrm{Cl}_{2}\right)$, chloroform (THF), dimethylformamide (DMF), ethanol $\left(\mathrm{C}_{2} \mathrm{H}_{5} \mathrm{OH}\right)$, water $\left(\mathrm{H}_{2} \mathrm{O}\right)$ and acetonitrile $\left(\mathrm{CH}_{3} \mathrm{CN}\right)$ was investigated for the $\mathrm{C}-\mathrm{H}$ activation of benzaldehyde in the presence of the catalyst and TBHP as a model reaction. The 
Table 1 Solvent type optimization for the model reaction ${ }^{a}$

\begin{tabular}{lll}
\hline Entry & Solvent & Yield $^{a}(\%)$ \\
\hline 1 & $\mathrm{CH}_{2} \mathrm{Cl}_{2}$ & Trace \\
2 & $\mathrm{THF}$ & 10 \\
3 & $\mathrm{DMF}$ & 20 \\
4 & $\mathrm{C}_{2} \mathrm{H}_{5} \mathrm{OH}$ & 15 \\
5 & $\mathrm{H}_{2} \mathrm{O}$ & 25 \\
6 & $\mathrm{CH}_{3} \mathrm{CN}$ & $\mathbf{8 2}$
\end{tabular}

${ }^{a}$ Reaction conditions: benzaldehyde $(1 \mathrm{mmol})$, TBHP $(1 \mathrm{mmol})$, catalyst (10 $\mathrm{mol} \%)$ and solvent $(2 \mathrm{ml})$.

results are summarized in Table 1 . It is obvious that the $\mathrm{C}-\mathrm{H}$ activation of benzaldehyde is solvent-dependent. It can be seen that the maximum yield was obtained with the $\mathrm{CH}_{3} \mathrm{CN}$ solvent. So, $\mathrm{CH}_{3} \mathrm{CN}$ was chosen as an ideal solvent for this reaction.

The effect of the amount of catalyst. For the investigation of the effect of the amount of catalyst on the $\mathrm{C}-\mathrm{H}$ activation of aldehydes, as mentioned above the reaction of benzaldehyde in $\mathrm{CH}_{3} \mathrm{CN}$ as the solvent in the presence of TBHP was chosen as the model reaction. As shown in Table 2, $10 \mathrm{~mol} \%$ of $\mathrm{Cu}-\mathrm{MOF}$ was the best amount of catalyst for the synthesis of benzoic anhydride. The higher amounts of catalyst did not affect the reaction distinctly (Table 2, entries 5 and 6).

Selection of the best oxidant. For the optimization and selection of the best oxidant, air, TBHP, $\mathrm{H}_{2} \mathrm{O}_{2}$ and oxone were chosen and as shown in Table 3, entry 4, the best oxidant for this reaction was TBHP. It is noteworthy that when hydrogen peroxide was used as an oxidant a large part of aldehyde was converted to carboxylic acid and no product was observed.

After optimization of the model reaction, the reaction generality was evaluated using a vast number of aromatic aldehydes. The results are summarized in Table 4 . The reaction presented good to excellent results using functionalized aromatic aldehydes with both electron-rich and electron-poor substituents. The results showed a high catalyst proficiency in $\mathrm{C}-\mathrm{H}$ bond activation and the synthesis of anhydrides. Patel et $a l .{ }^{32}$ have reported that aldehydes with electron-withdrawing groups such as $\mathrm{NO}_{2}$ in para or ortho positions in the presence of $\mathrm{CuO}$ nanoparticles resulted in no product being formed, while in the present work aldehydes with electron-withdrawing groups led to the corresponding anhydrides in relatively good yields. On the other hand, aldehydes with electron-donating

Table 2 Optimization of the amount of $\mathrm{Cu}_{2}(\mathrm{BDC})_{2}(\mathrm{DABCO})$ catalyst in the synthesis of benzoic anhydride

\begin{tabular}{lll}
\hline Entry & Amount of catalyst (mol\%) & Yield $^{a}(\%)$ \\
\hline 1 & 1 & 41 \\
2 & 2.5 & 52 \\
3 & 5 & 60 \\
4 & 10 & 82 \\
5 & 20 & 81 \\
6 & $\mathbf{3 0}$ & $\mathbf{8 3}$
\end{tabular}

${ }^{a}$ Reaction conditions: benzaldehyde $(1 \mathrm{mmol})$, TBHP $(1 \mathrm{mmol})$ and $\mathrm{CH}_{3} \mathrm{CN}(2 \mathrm{ml})$.
Table 3 Effect of the type of oxidant in the synthesis of benzoic anhydride

\begin{tabular}{|c|c|c|}
\hline Entry & Oxidant & Yield $^{a}(\%)$ \\
\hline 1 & Air & - \\
\hline 2 & Oxone & - \\
\hline 3 & $\mathrm{H}_{2} \mathrm{O}_{2}$ & - \\
\hline 4 & TBHP & 82 \\
\hline
\end{tabular}

groups such as vaniline, 4-methoxy benzaldehyde and 4hydroxy benzaldehyde were converted to anhydrides with good to excellent yields.

In line with the results reported earlier by Saberi et al., and Khatun et al. the reaction of benzaldehyde in the presence of $\mathrm{CuCl}$ and $\mathrm{CuCl}_{2}$ and TBHP yielded 68 and $75 \%$ of the corresponding anhydrides, $2 \mathrm{a}$, after $3 \mathrm{~h}$, respectively (Table 5, entry 3 and 4). However, when $\mathrm{CuCl}$ and $\mathrm{CuCl}_{2}$ were replaced by $\mathrm{Cu}_{2}$ $(\mathrm{BDC})_{2} \mathrm{DABCO}$, the reaction was considerably faster and afforded practically full conversion and full selectivity to $2 \mathrm{a}$ after $2 \mathrm{~h}$ (Table 5, entry 7). In addition, after the completion of the reaction, the catalyst was easily separated by filtration or by centrifuge and reused several times. As shown in Table 5, also, there are many other reports on the synthesis of anhydrides using aldehydes, but most of them have used an equivalent amount of reagents and some of them are expensive and

Table 4 Generality investigation of the reaction through the synthesis of a vast number of asymmetric carboxylic anhydrides

\begin{tabular}{lllll}
\hline & & & \\
& & & \\
& & &
\end{tabular}

${ }^{a}$ Reaction conditions: aromatic aldehydes $(1 \mathrm{mmol})$, TBHP $(1.5 \mathrm{mmol})$ and time: $2 \mathrm{~h}$. 
Table 5 Comparison of the activity for different systems in the synthesis of benzoic anhydride

\begin{tabular}{|c|c|c|c|c|c|}
\hline Entry & Catalyst & Reaction conditions & Time & Yield & Ref. no. \\
\hline 1 & - & $\mathrm{CH}_{2} \mathrm{Cl}_{2}, \mathrm{TCCA}, \mathrm{Et}_{3} \mathrm{~N}$ & $1 \mathrm{~h}$ & 98 & 26 \\
\hline 2 & CuO nanoparticle & DCE, TBHP $120^{\circ} \mathrm{C}$ & $5 \mathrm{~h}$ & 61 & 32 \\
\hline 4 & $\mathrm{CuCl}$ & DMSO, TBHP, rt & $1 \mathrm{~h}$ & 75 & 31 \\
\hline 5 & - & TBHP, TBAI, $\mathrm{CH}_{3} \mathrm{CN}, 70^{\circ} \mathrm{C}$ & $0.5 \mathrm{~h}$ & 87 & 28 \\
\hline 6 & - & TBHP, TBAI, $\mathrm{PhClO}, 80^{\circ} \mathrm{C}$ & 3 & 85 & 29 \\
\hline
\end{tabular}

environmentally destructive (Table 5, entry 1, 5 and 6 ). On the other hand, $\mathrm{CuO}$ particles displayed the worst catalytic performance (61\% conversion), which indicates the crucial role of the microporous structure of $\mathrm{Cu}-\mathrm{MOF}$, which provides a higher availability of copper sites compared to the very low porosity structure of $\mathrm{CuO}^{32}$ (Table 5, entry 2). As a result, Cu-MOF is expected to have flexible and unsaturated coordination for aldehydes, which allows for the continuation of the reaction process and the avoidance of the reaction being blocked by very rigid coordination. ${ }^{42,43}$

The proposed reaction mechanism is shown in Scheme 3.

In this reaction, firstly, electron transfer from an exposed $\mathrm{Cu}$ (II) at $\mathrm{Cu}-\mathrm{MOF}$ to TBHP generates $\mathrm{Cu}$ (III) and ${ }^{t} \mathrm{BuO}^{\circ}$. Then, $\mathrm{Cu}$ (III) eliminates an electron from the other TBHP molecule and gives $\mathrm{Cu}(\mathrm{II})$ and ${ }^{t} \mathrm{BuOO}{ }^{*}$ species. The activation of the hydrogen atom from aldehyde by ${ }^{t} \mathrm{BuO}$ ' led to the formation of a benzoyl radical which coupled with ${ }^{t} \mathrm{BuOO}$ ', subsequently. Then the cleavage of the $\mathrm{O}-\mathrm{O}$ bond in the $\mathrm{RCOOO}^{t} \mathrm{Bu}$ intermediate and it coupling with another benzoyl radical resulted in the corresponding anhydride and ${ }^{t} \mathrm{Buo}{ }^{\circ}$ species, which could be used in attracting the $\mathrm{C}-\mathrm{H}$ bond of aryl-aldehyde. ${ }^{26}$

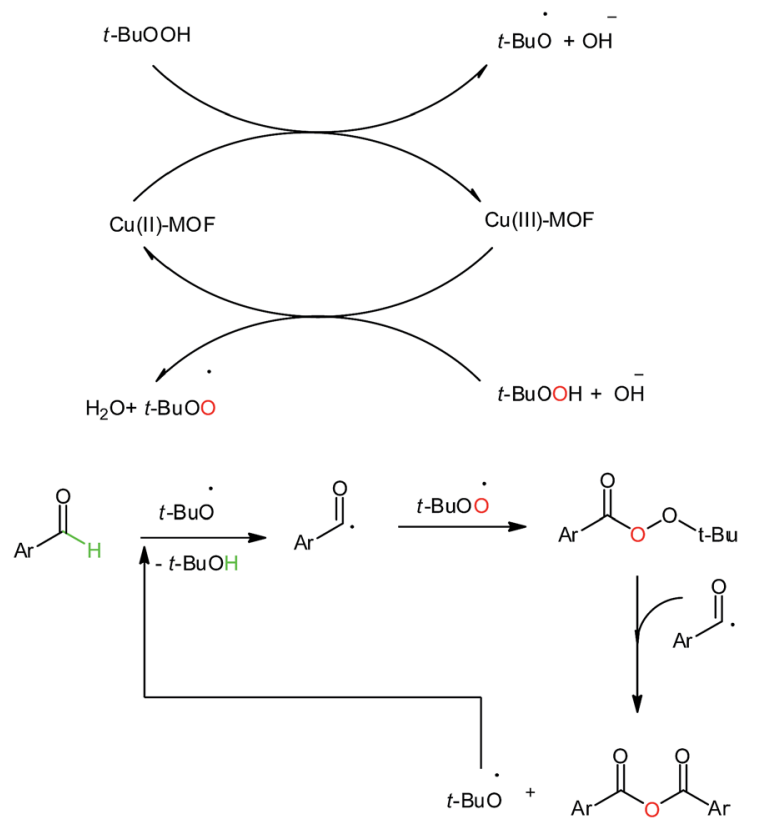

Scheme 3 The proposed mechanism for the synthesis of symmetric carboxylic anhydrides via $\mathrm{C}-\mathrm{H}$ activation.
One of the important issues for heterogeneous catalysts is reusability. To investigate this issue for our catalyst, $\mathrm{Cu}-\mathrm{MOF}$ was recovered by simple filtration and washed with methanol and dried in an oven. The recovered catalyst was reused for the $\mathrm{C}-\mathrm{H}$ activation of benzaldehyde and the formation of benzoic anhydride four times. The results indicate that $\mathrm{Cu}_{2}(\mathrm{BDC})_{2} \mathrm{DABCO}$ can be used for several cycles successfully with minimal loss of activity. As it is clear from the FESEM images, the morphology of the structure is not changed after 4 runs (Fig. 1).

The TEM image of recycled $\mathrm{Cu}_{2}(\mathrm{BDC})_{2} \mathrm{DABCO}$ shows that the crystalline structure of $\mathrm{Cu}_{2}(\mathrm{BDC})_{2} \mathrm{DABCO}$ is maintained after 5 runs (Fig. 2).

Recycled $\mathrm{Cu}_{2}(\mathrm{BDC})_{2} \mathrm{DABCO}$ after 5 runs maintained its crystallinity based on PXRD (Fig. 3), but a slight degradation of the structure and hydrolysis reaction ${ }^{44,45}$ could possibly justify the presence of the peaks at higher values of $2 \theta\left(30-40^{\circ}\right)$, which probably indicates the presence of $\mathrm{Cu}(\mathrm{OH})_{2}$ or $\mathrm{CuO},{ }^{46}$ which are direct products of this reaction. In fact, under TBHP $(70 \%)$

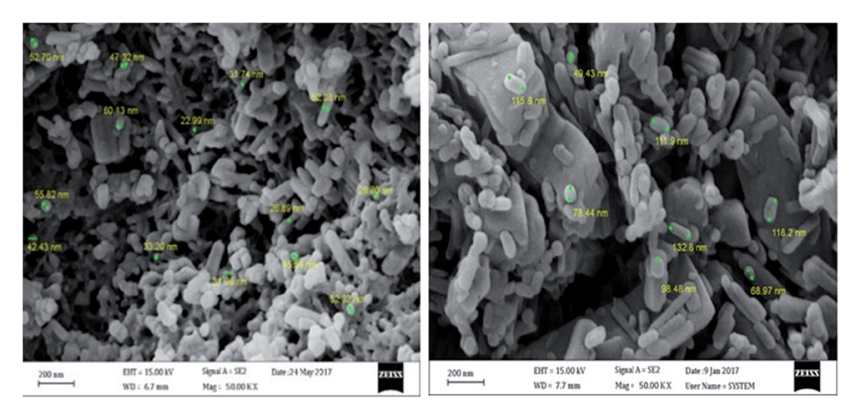

Fig. 1 The FE-SEM image of fresh $\mathrm{Cu}_{2}(\mathrm{BDC})_{2} \mathrm{DABCO}$ (left) and the FESEM image of recycled $\mathrm{Cu}_{2}(\mathrm{BDC})_{2} \mathrm{DABCO}$ (right).
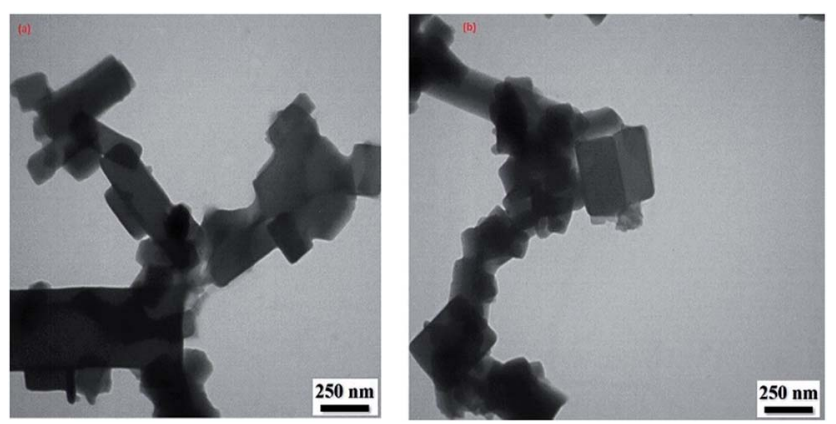

Fig. 2 The TEM image of fresh $\mathrm{Cu}_{2}(\mathrm{BDC})_{2}(\mathrm{DABCO})$ (left) and the TEM image of recycled $\mathrm{Cu}_{2}(\mathrm{BDC})_{2}(\mathrm{DABCO})$ (right). 


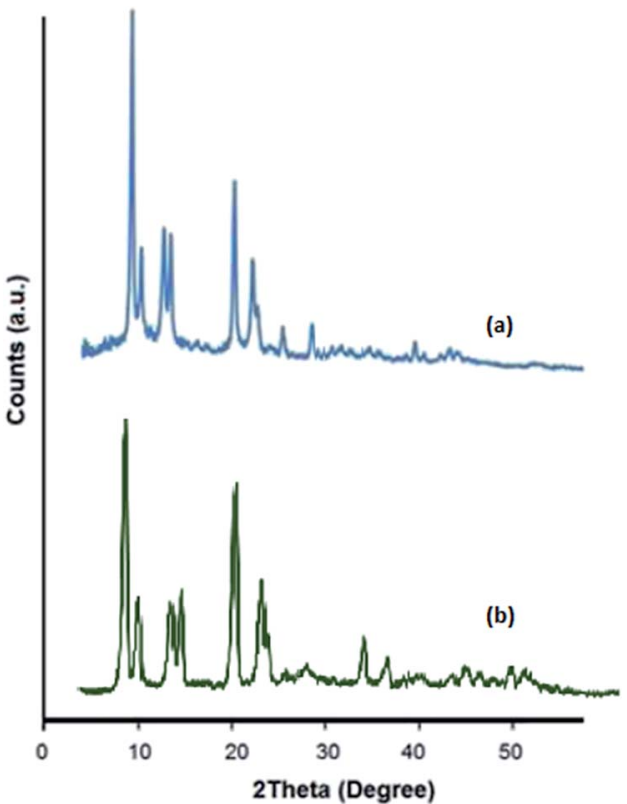

Fig. 3 (a) The XRD pattern of fresh $\mathrm{Cu}_{2}(B D C)_{2}(\mathrm{DABCO})$. (b) The XRD pattern of recycled $\mathrm{Cu}_{2}(\mathrm{BDC})_{2}(\mathrm{DABCO})$.

conditions, little water molecules are able to condense into the cavities of the material and it finally becomes energetically favorable for $\mathrm{H}_{2} \mathrm{O}$ to hydrolyze the $\mathrm{Cu}-\mathrm{O}$ bond, breaking the crystalline structure. ${ }^{44,45}$

\section{Conclusion}

In conclusion, we have studied a simple and effective method for the preparation of symmetric carboxylic anhydrides via $\mathrm{C}-\mathrm{H}$ aldehyde bond activation catalyzed by $\mathrm{Cu}-\mathrm{MOF}$. In regards to the significant catalytic activity of $\mathrm{Cu}_{2}(\mathrm{BDC})_{2}(\mathrm{DABCO})$, a wide range of aromatic aldehydes with electron-donating groups and electron-withdrawing groups were converted to the corresponding anhydrides rapidly with good to excellent yields. Also, aldehydes with electron-withdrawing groups that had no yield in the methods reported in the literature were produced with relatively good efficiency using our method.

\section{Conflicts of interest}

There are no conflicts to declare.

\section{Acknowledgements}

We acknowledge the Science and Research Branch of Islamic Azad University for the partial financial support of this work.

\section{References}

1 X. Hu, X. Lou, C. Li, Q. Chen, Q. Yang and B. Hu, New J. Chem., 2017, 41, 6415-6419.

2 S. R. Batten, N. R. Champness, X. Chen, J. Garcia-Martinez, S. Kitagawa, L. Ohrstrom, M. O'Keeffe, M. P. Suh and J. Reedijk, CrystEngComm, 2012, 14, 3001-3004.
3 S. M. Sadeghzadeh, R. Zhiani and S. Emrani, New J. Chem., 2018, 42, 988-994.

4 F. Rouhani and A. Morsali, New J. Chem., 2017, 41, 1547515484.

5 Y. Takashima, M. Yokoyama, A. Horikoshi, Y. Sato, T. Tsuruoka and K. Akamatsu, New J. Chem., 2017, 41, 14409-14413.

6 M.-X. Wu and Y.-W. Yang, Adv. Mater., 2017, 29, 3103-3121.

7 M. Al Haydar, H. R. Abid, B. Sunderland and S. Wang, Drug Des., Dev. Ther., 2017, 11, 2685-2695.

8 B. Li, H. M. Wen, W. Zhou and B. Chen, J. Phys. Chem. Lett., 2014, 5, 3468-3479.

9 S. Ma and H. C. Zhou, Chem. Commun., 2010, 46, 44-53.

10 H. Furukawa, F. Gándara, Y. B. Zhang, J. Jiang, W. L. Queen, M. R. Hudson and O. M. Yaghi, J. Am. Chem. Soc., 2014, 136, 4369-4381.

11 Z. Hu, B. J. Deibert and J. Li, Chem. Soc. Rev., 2014, 21, 58155840.

12 L. E. Kreno, K. Leong, O. K. Farha, M. Allendorf, R. P. Van Duyne and J. T. Hupp, Chem. Rev., 2012, 112, 1105-1125.

13 J. W. Maina, C. Pozo-Gonzalo, L. Kong, J. Schütz, M. Hill and L. F. Dumée, Mater. Horiz., 2017, 4, 345-361.

14 M. Ghorbanlooa, V. Safarifard and A. Morsali, New J. Chem., 2017, 41, 3957-3965.

15 J. Liu, L. Chen, H. Cui, J. Zhang, L. Zhang and C.-Y. Su, Chem. Soc. Rev., 2014, 43, 6011-6061.

16 A. Dhakshinamoorthy and H. Garcia, Chem. Soc. Rev., 2014, 43, 5750-5765.

17 A. Dhakshinamoorthy, M. Alvaro and H. Garcia, Catal. Sci. Technol., 2011, 1, 856-867.

18 W. J. Shen, Y. Zhuo, Y. Chai and R. Yuan, Anal. Chem., 2015, 87, 11345-11352.

19 M. A. Ogliaruso and J. F. Wolfe, Synthesis of Carboxylic Acids, Esters and Their Derivatives, John Wiley \& Sons, New York, 1991, pp. 198-217.

20 T. Mukaiyama, J. Izumi, M. Miyashita and I. Shiina, Chem. Lett., 1993, 22, 907-910.

21 I. Shiina, K. Nakata, K. Ono, Y. Onda and M. Itagaki, J. Am. Chem. Soc., 2010, 132, 11629-11641.

22 I. Shiina, Tetrahedron, 2004, 59, 1587-1599.

23 (a) N. F. Albertson, Organic Reactions: Synthesis of Peptides with Mixed Anhydrides, John Wiley \& Sons, Inc, 2011; (b) F. M. F. Chen, R. Stainauer and N. L. Benoiton, J. Org. Chem., 1983, 48, 2939-2941.

24 J. Kim and D. O. Jang, Synth. Commun., 2001, 31, 395-399. 25 C. Robert, F. de Montigny and Ch. M. Thomas, ACS Catal., 2014, 4, 3586-3589.

26 (a) S. Gaspa, A. Porcheddu and L. De Luca, Tetrahedron Lett., 2017, 58, 2533-2536; (b) S. Gaspa, I. Amura, A. Porcheddu and L. D. Luca, New J. Chem., 2017, 41, 931-939.

27 P. Chauhan, M. Ravi, R. Kant and P. Yadav, Org. Biomol. Chem., 2017, 15, 1080-1085.

28 R. Singha, M. Ghosh, Y. Nuree and J. K. Ray, Tetrahedron Lett., 2016, 57, 1325-1327.

29 M. Adib, R. Pashazadeh, S. Rajai-Daryasarei, P. Mirzaei and S. J. A. Gohari, Tetrahedron Lett., 2016, 57, 3071-3074. 
30 D. Saberi, F. Shojaeyan and K. Niknam, Tetrahedron Lett., 2016, 57, 566-569.

31 Y. Nuree, R. Singha, M. Ghosh, P. Roy and J. K. Ray, Tetrahedron Lett., 2016, 57, 1479-1482.

32 N. Khatun, S. K. Santra, A. Banerjee and B. K. Patel, Eur. J. Org. Chem., 2015, 1309-1313.

33 S. Santoro, S. I. Kozhushkov, L. Ackermann and L. Vaccaro, Green Chem., 2016, 18, 3471-3493.

34 I. Luz, A. Corma and F. X. L Xamena, Catal. Sci. Technol., 2014, 4, 1829-1836.

35 S. Akbari, J. Mokhtari and Z. Mirjafary, RSC Adv., 2017, 7, 40881-40886.

36 A. Khosravi, J. Mokhtari, M. R. Naimi-Jamal, S. Tahmasebi and L. Panahi, RSC Adv., 2017, 7, 46022-46027.

37 L. Panahi, M. Reza Naimi-Jamal, J. Mokhtari and A. Morsali, Microporous Mesoporous Mater., 2017, 244, 208-217.

38 Dictionary of Analytical Reagents, ed. A. Townshend, D. T. Burns, R. Lobinski, E. J. Newman, G. Guilbault, Z. Marczenko and H. Onishi, CRC Press Book, 1993, p. 175.
39 M. S. Newmann and J. A. Cella, J. Org. Chem., 1974, 39, 20842087.

40 Y. L. Hu, X. E. Zhao and M. Lu, Bull. Chem. Soc. Ethiop., 2011, 25, 255-262.

41 Z. J. Kaminski, B. Kolesinska and M. Małgorzata, Synth. Commun., 2004, 34, 3349-3358.

42 P. Valvekens, F. Vermoortele and D. De Vos, Catal. Sci. Technol., 2013, 3, 1435-1445.

43 Y. Jiang, J. Huang, M. Hunger, M. Maciejewski and A. Baiker, Catal. Sci. Technol., 2015, 5, 897-902.

44 P. M. Schoenecker, C. G. Carson, H. Jasuja, C. J. J. Flemming and K. S. Walton, Ind. Eng. Chem. Res., 2012, 51, 6513-6519.

45 M. todaro, G. Buscarino, L. Sciortino, A. Alessi, F. Messina, M. Taddei, M. Ranocchiari, M. Cannas and F. M. Gelardi, J. Phys. Chem. C, 2016, 120, 12879-12889.

46 N. Ba, L. Zhu, G. Zhang, J. Li and H. Li, Sens. Actuators, B, 2016, 227, 142-148. 